\title{
The application of the capillary-papain technique to the rapid matching of blood for transfusion
}

\author{
B. E. GILBEY AND JOAN M. LINDARS \\ From West Middlesex Hospital, Isleworth, Middlesex
}

SYNOPSIS An application of the capillary-papain technique to the rapid cross-matching of blood for transfusion is described. The test can be performed in 15 minutes and is simple to carry out and interpret. It is inferior to the indirect Coombs test in detecting antibodies belonging to blood groups other than the $\mathrm{Rh}$ system.

Rapid methods of cross-matching have an important place in emergency transfusion work. The object of this paper is to describe the application of the capillary-papain technique for rapid $R h$ typing (Gilbey, 1961) to emergency cross-matching and to offer experimental evidence of its reliability in comparison with the indirect Coombs test and certain albumin techniques.

\section{EXPERIMENTAL}

The technique employed was essentially similar to that previously described for rapid $\mathrm{Rh}$ typing, the serum of the recipient being substituted for the anti-D typing serum. A mixture of equal parts of recipient's serum and Löw's activated papain solution was run into a capillary tube $8 \mathrm{in}$. in length and 1 to $2 \mathrm{~mm}$. in bore, the column of mixture being approximately 2 in. in length. An equal volume of $25 \%$ suspension of washed donor red cells in saline was allowed to run into the serum-papain mixture. The lower end of the capillary tube was plugged with plasticine and the tube incubated for 15 minutes at $37^{\circ} \mathrm{C}$. at an angle of $45^{\circ}$ with the red-cell layer uppermost. At the end of this time the results were read macroscopically or with a hand lens. Any tubes showing a 'beaded' appearance were considered incompatible.

\section{RESULTS}

TITRATION VALUES Titrations were carried out on 10 anti-D sera using the capillary-papain, indirect Coombs, and three different albumin techniques. As shown in Table I, the capillary-papain titres compared well with those obtained by the other methods. It is noteworthy that the standard albumin tube method using a $3 \%$ suspension of red cells in albumin and two hours' incubation gave substantially lower values than any of the other methods.

TESTS AGAINST WEAK ANTI-D SERA Tests were made on 48 anti-D sera, most of which contained only weak or poorly reacting antibodies, using the capillary-papain, indirect Coombs, albumin addition, albumin replacement, and $3 \%$ red cells in albumin techniques and also the method involving 20 minutes' incubation of the antiserum with $3 \%$ red cells in $30 \%$ albumin followed by centrifuging for one minute at 1,000 r.p.m. From Table II it will be seen that while the capillary-papain and the indirect Coombs techniques gave positive results with all 48 sera, all the albumin techniques gave a proportion of false negative or doubtful results. Again, the

TABLE I

COMPARATIVE TITRATION VALUES FOR FIVE TECHNIQUES USING FRESH D-POSITIVE RED CELLS

Technique and Incubation Time Anti-D Sera

\begin{tabular}{llllllllll}
\hline 1 & 2 & 3 & 4 & 5 & 6 & 7 & 8 & 9 & 10
\end{tabular}

Capillary-papain, $15 \mathrm{~min}$.

Indirect Coombs, $2 \mathrm{hr}$.

Albumin addition, $2 \mathrm{hr}$.

Albumin replacement, $2 \mathrm{hr}$.

$3 \%$ cells in albumin, $2 \mathrm{hr}$.

Received for publication 28 June 1961 
TABLE II

RELATIVE SENSITIVITY OF CAPILLARY-PAPAIN AND OTHER TECHNIQUES USING WEAK ANTI-D SERA AND FRESH D-POSITIVE RED CELLS

\begin{tabular}{|c|c|c|c|c|}
\hline $\begin{array}{l}\text { Technique and } \\
\text { Incubation Time }\end{array}$ & Positive & Negative & Doubtful & Total \\
\hline $\begin{array}{l}\text { Capillary-papain, } 15 \mathrm{~min} \text {. } \\
\text { Indirect Coombs, } 2 \mathrm{hr} \text {. } \\
\text { Albumin addition, } 2 \mathrm{hr} \text {. } \\
\text { Albumin replacement, } 2 \mathrm{hr} \text {. } \\
3 \% \text { cells in albumin, } 2 \mathrm{hr} \text {. } \\
20 \mathrm{~min} \text {. incubation with } \\
\text { cells in albumin followed } \\
\text { by } 1 \mathrm{~min} \text {. centrifuging } \\
\text { at } 1,000 \text { r.p.m. }\end{array}$ & $\begin{array}{r}48 \\
48 \\
46 \\
44 \\
40\end{array}$ & $\begin{array}{l}0 \\
0 \\
0 \\
1 \\
8\end{array}$ & $\begin{array}{l}0 \\
0 \\
2 \\
3 \\
0\end{array}$ & $\begin{array}{l}48 \\
48 \\
48 \\
48 \\
48\end{array}$ \\
\hline
\end{tabular}

technique using $3 \%$ red cells in albumin with two hours' incubation gave the poorest performance.

TESTS AGAINST STORED DONOR BLOOD Using the capillary-papain technique, 10 anti-D sera, selected as being the weakest and most poorly reacting of those sera previously tested (Table II), were each matched against five pilot samples of D-positive donor blood from transfusion bottles, the age of these samples ranging from 12 to 17 days. The doncr samples had been stored under normal blood bank conditions at $4^{\circ} \mathrm{C}$. Of the 10 sera tested, eight gave positive results with all five of the pilot samples, 36 being excellent macroscopic positives and four being readily confirmed with a hand lens. Serum 4 and serum 8 gave negative results with certain pilot samples. These negative findings were confirmed by the indirect Coombs technique. A further six pilot samples gave unequivocal positives when tested against these two sera (Table III). On subtyping the negatively reacting pilot samples it was found that they were of the same Rh phenotype as the fresh D-positive cells with which the sera 4 and 8 had already given positive results, i.e., CDce. Whether
TABLE III

REACTIONS OF SERA 4 AND 8 WITH STORED D-POSITIVE DONOR CELLS

\begin{tabular}{cccccc} 
Cell & \multicolumn{2}{c}{ Capillary-Papain } & & \multicolumn{2}{c}{ Indirect Coombs } \\
\cline { 2 - 3 } \cline { 5 - 6 } & Serum 4 & Serum 8 & & Serum 4 & Serum 8 \\
\hline 1 & V & V & & \\
2 & V & V & & \\
3 & V & V & & & \\
4 & - & - & & \\
5 & + V & V & & & \\
6 & V & V & & \\
7 & V & V & & \\
8 & V & V & & \\
9 & V & V & & \\
10 & & V & & & \\
11 & & & & &
\end{tabular}

$\mathbf{V}=$ gross macroscopic positive

$++=$ macroscopic positive confirmed with hand lens =negative reaction

these false negatives were due to the poor reacting qualities of the sera or to the condition of the pilot sample we cannot say. The fact that the negative findings were confirmed by the indirect Coombs test suggests that these false negatives were not due to lack of sensitivity of the capillary-papain technique.

TESTS AGAINST ANTIBODIES OTHER THAN ANTI-D A number of sera containing $\mathrm{Rh}$ antibodies other than anti-D were tested, together with sera containing antibodies for systems other than Rh (Table IV). The capillary-papain technique behaved very well indeed with the other antibodies of the $R h$ system, but, as was expected, its reliability fell away sharply when non- $R h$ antibodies were involved. All the $R h$ antibodies gave positive results but of the other antibodies only anti-Kell gave a substantial proportion of positives.

TESTS FOR FALSE POSITIVE REACTIONS Serum samples

TABLE IV

LIMITATIONS OF CAPILLARY-PAPAIN TECHNIQUE WHEN APPLIED TO DETECTION OF ANTIBODIES OTHER THAN ANTI-D

\begin{tabular}{|c|c|c|c|c|c|c|c|}
\hline \multirow[t]{2}{*}{ Antibody } & \multicolumn{2}{|c|}{ Capillary-Papain, $37^{\circ} \mathrm{C}$. } & \multicolumn{2}{|c|}{ Indirect Coombs, $37^{\circ} \mathrm{C}$} & \multicolumn{2}{|c|}{ Saline, $20^{\circ} \mathrm{C}$} & \multirow{2}{*}{ Total } \\
\hline & Positive & Negative & Positive & Negative & Positive & Negative & \\
\hline $\begin{array}{l}\text { Anti-C } \\
\text { Anti-E } \\
\text { Anti-c } \\
\text { Anti-e } \\
\text { Anti-Kell } \\
\text { Anti-S } \\
\text { Anti-Fya } \\
\text { Anti-Le' } \\
\text { Anti-Leb } \\
\text { Anti-Lua } \\
\text { Anti-P }\end{array}$ & $\begin{array}{l}4 \\
8^{1} \\
6^{1} \\
1 \\
3 \\
0 \\
0 \\
1^{2} \\
0 \\
0 \\
1\end{array}$ & $\begin{array}{l}0 \\
0 \\
0 \\
0 \\
1 \\
2 \\
2 \\
1 \\
1 \\
2 \\
1\end{array}$ & $\begin{array}{l}4 \\
8 \\
6 \\
1 \\
4 \\
2 \\
2\end{array}$ & $\begin{array}{l}\mathbf{0} \\
\mathbf{0} \\
\mathbf{0} \\
\mathbf{0} \\
\mathbf{0} \\
\mathbf{0} \\
\mathbf{0}\end{array}$ & $\begin{array}{l}2 \\
1 \\
2 \\
2\end{array}$ & $\begin{array}{l}0 \\
0 \\
0 \\
0\end{array}$ & $\begin{array}{l}4 \\
8 \\
6 \\
1 \\
4 \\
2 \\
2 \\
2 \\
1 \\
2 \\
2\end{array}$ \\
\hline
\end{tabular}

'These sera had been stored for between 15 and 20 years at $-20^{\circ} \mathrm{C}$.

'This anti-Lea reacted in saline at $37^{\circ} \mathrm{C}$. as well as at $20^{\circ} \mathrm{C}$. 
from 400 unselected hospital in-patients were tested using OD-positive red cells. No false positive results were obtained in this series.

\section{A NOTE ON THE STORAGE OF LÖW'S ACTIVATED PAPAIN SOLUTION}

A recent trial by us has suggested that Löw's activated papain solution retains its activity if preserved by freeze-drying. Freeze-dried samples, prepared in the normal way and stored for six weeks at normal laboratory temperatures of $20^{\circ} \mathrm{C}$. to $22^{\circ} \mathrm{C}$., maintained their activity perfectly, dissolving immediately to a clear solution. The possibility of storing this material over considerable periods without the necessity of refrigeration is an attractive one and this enquiry is being pursued in tests over longer time intervals.

\section{DISCUSSION}

The capillary-papain technique described is designed as a rapid technique capable of detecting many of the immune antibodies likely to be met with in transfusion practice. It is evident from the results given in Table IV that it will not with any degree of reliability detect immune antibodies other than those of the $R h$ system. However, no technique is entirely without its limitations (Mollison, 1956), and if one considers the speed at which the capillary-papain test can be performed under emergency conditions and the degree of protection offered to the patient in comparison with that given by much longer albumin techniques, then, provided its limitations are recognized, it should prove useful in emergencies.

The technique is a simple one and reliable even in the hands of relatively inexperienced workers, the results being clear-cut and easy to interpret. However, Hekker, Klomp-Magnee, Krijnen, and van Loghem (1957) reported that serum-papain mixtures lost activity fairly rapidly and that even after 15 minutes a marked loss in activity could be demonstrated. This has also been our experience and we therefore consider it essential that the serum-papain mixture used for cross-matching be used at once if maximum enzyme activity is to be obtained, especially if very weak antibodies are to be detected. The clear-cut results obtained by us with weak anti-D sera are in contrast to the results obtained with albumin techniques, all of which gave varying numbers of equivocal results.

Our findings regarding the detection of anti-Kell by the capiliary-papain technique were similar to the results obtained with a larger panel of anti-Kell sera by Lewis, Hiroko, and Chown (1958).

While it is accepted that any doubtful reaction would automatically lead to the rejection of the donor, the false negative reactions obtained with certain albumin techniques in the presence of weak $\mathrm{Rh}$ antibodies are disturbing.

Under no circumstances would we suggest that the capillary-papain replace the indirect Coombs test as the single method of choice, in view of its poor performance with antibodies other than those against rhesus antigens, but there is a considerably greater likelihood of the rarer $\mathrm{Rh}$ antibodies being present in a recipient's serum than there is of those belonging to other blood group systems. The number of tests carried out with anti-C, anti-E, anti-c, and anti-e was necessarily small, but our findings suggest that in the detection of these antibodies the capillarypapain test is as reliable as in the detection of anti-D.

We would like to thank Dr. A. E. Mourant, of the Blood Group Reference Laboratory, Lister Institute, London, for the supply of many of the sera used in this work. Our thanks are also due to Miss P. R. N. Kind for her help with the freeze-drying experiments and to Dr. M. Lubran and Dr. J. G. Selwyn for their advice and criticism.

\section{REFERENCES}

Gilbey, B. E. (1961). J. clin. Path., 14, 444.

Hekker, A. C., Klomp-Magnee, W., Krijnen, H. W., and Loghem, J. J. van, Jr. (1957). Vox Sang. (Basel), n.s. 2, 128.

Lewis, M., Hiroko, K., and Chown, B. (1958). J. Lab. clin. Med. 52 , 163.

Mollison, P. L. (1956). Blood Transfusion in Clinical Medicine, 2nd ed., pp. 311-312. Blackwell, Oxford. 